Department of Natural and Mathematical disciplines,

Lutsk Pedagogical College

36, Volya Avenue, Lutsk, Ukraine

\title{
THE USE OF THE MOZAIK INTERACTIVE PLATFORM AS A SOCIAL OBJECT FOR EDUCATIONAL INTERACTION BETWEEN THE PARTICIPANTS OF THE LEARNING PROCESS
}

The article characterizes the Mozaik interactive platform and its main components - mozaBook and mozaWeb, which are used by lecturers-philologists to give classes on the Ukrainian language to undergraduate students whose specialization is "Secondary Education" (educational program "Ukrainian Language and Literature. World Literature"). The possibilities of use of the software at different stages of educational process have been described. The didactic functions of the use of the mentioned resources in the process of teaching the disciplines "Practicum on the Ukrainian language" and "Methodology of teaching the Ukrainian language" have been outlined. The mozaBook software has been analyzed as a social object which provides pedagogical interaction of scientific methodology of rational-logical thinking with emotional and imaginative presentation and perception of information. The possibilities of mozaBook and mozaWeb have been used to improve the perception and acquisition of scientific information and to increase the level of educational achievements. The authors have analyzed the expediency of using e-textbooks, media library, software for attaching information of various types and use of mozaBook tools ("Spelling and grammar", "Parts of speech", "Dictionary cards", "Language games", "Questionnaire", "Decoding", "Tests") while explaining and illustrating theoretical material, summarizing and systematizing material that has already been learned. It has been shown that the Mozaik interactive platform and its components make the classes more informative, compact, emotionally attractive, mobile and multifunctional.

Keywords: Mozaik interactive platform, mozaBook, mozaWeb, social system, social object, tools, didactic function, cloud environment.

Подано до редакиії 15.05.2020

УдК 612+616-056.2-057.87(5-15)

DOI: https://doi.org/10.24195/2414-4665-2020-1-11

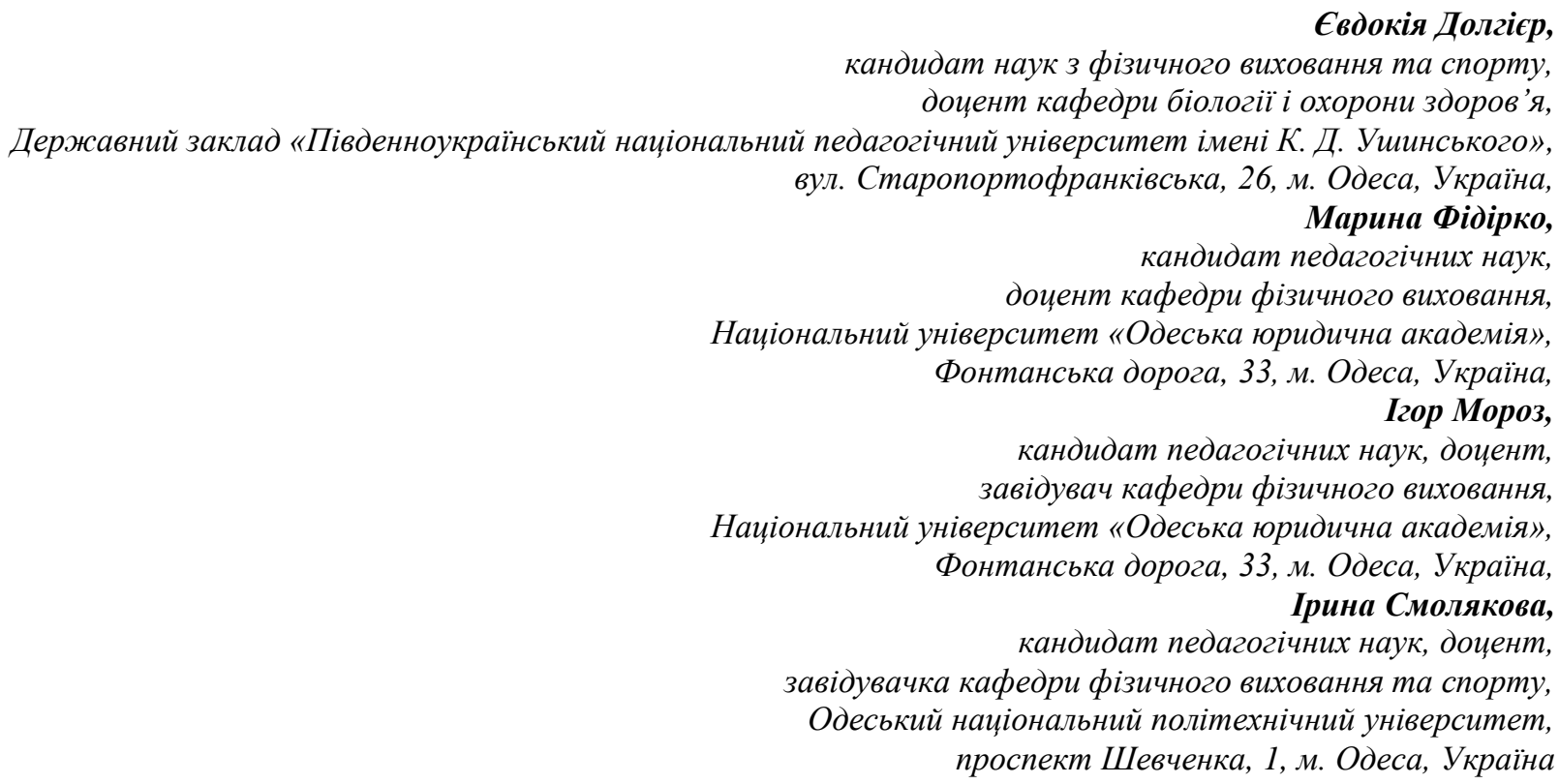

ДОСЛІДЖЕННЯ ФІЗИЧНОГО СТАНУ СТУДЕНТІВ 3 КРАЇН БЛИЗЬКОГО СХОДУ

У статті аналізується проблема сучасних уявлень про фізіологічні механізми, які підтримують стан здоров'я іноземних студентів у системі організм-середовище в умовах навчання у закладах вищої освіти України. Поставлено за мету дати порівняльну характеристику фізичного стану студентів з крайн Близького Сходу. У дослідженні брали участь студенти-чоловіки IV року навчання з Сгипту та Ізраӥлю. Проведено аналіз спеціальної науково-методичної літератури, параметрів фізичного розвитку та показників діяльності сериевоScience and Education, 2020, Issue 1 
-судинної та вегетативної нервової систем, фізичної праџездатності. Дослідження показало переважання морфофункиіональних показників обстежених ізраїльтян в порівнянні зі студентами з Сгипту за життєвим індексом, силовим індексом кистьової та станової динамометрії, екскурсією грудної клітки. Вірогідно більша кількість студентів з Сгипту (36,4\%) мала надлишкову масу тіла, ніж студентів з Ізраїлю (8,3\%). За індексом Кердо, орто- та кліностатичною пробою, які характеризують вплив симпатичної або парасимпатичної гілок вегетативної регуляиії, отримані вірогідні $(p \leq 0,05)$ відмінності між групами обстежуваних, щзо дозволяє стверджувати про незбалансовану вегетативну регуляцію організму іноземних студентів, так, в певній мірі у студентів з Ізраїлю є схильність до переважання парасимпатикотонічних впливів, тоді як в студентів з Єгипту - схильність до переважання симпатикотонічних ефектів. Вивчення типів реакиї серцево-судинної системи на дозоване фізичне навантаження та фізичної праџездатності свідчить, щуо у більшості обстежених іноземних студентів спостерігалися нормотензивний тип реакції на фізичне навантаження, високий та вище за середній рівень фізичної працездатності. За даними проведеного дослідження, виявлено негативний вплив навколишнього середовища на механізми вегетативного забезпечення діяльності сериево-судинної системи, щзо потребує певної уваги та своєчасної адекватної корекиії з метою профілактики розладів у нервовій діяльності та адаптаційних можливостях організму обстежених.

Ключові слова: іноземні студенти, фізичний стан, фізичний розвиток, функціональний стан.

\section{блеми}

Вступ та сучасний стан досліджуваної про-

Сучасні умови навчання у закладах вищої освіти пов'язані із глобалізацією та трансформацією економіки України, орієнтованої на європейські стандарти, які вимагають вирішення низки проблем, у тому числі щодо функціонування ринку освітніх послуг. Залучення до навчання іноземних студентів є одним із засобів подолання можливої кризи у зв'язку з неефективністю механізму державного фінансування системи освіти. В контексті забезпечення конкурентоспроможності навчання студентів-іноземців особливої уваги потребують питання успішного освоєння ними освітніх програм. Відомо, що особливості навчання цього контингенту виражаються у проблемах, які істотно відрізняються від складнощів навчання вітчизняних студентів, що пов'язані із зміною соціокультурного середовища, нової освітньої системи, інтернаціонального характеру груп, клімато-географічних умов. Слід зазначити, що іноземні студенти з країн Близького Сходу стикаються із контрастністю між умовами місця постійного й тимчасового мешкання, змінами у харчуванні, екстремальним впливом незвичної кліматичної зони, які відображаються у важкому звиканні до специфічного температурного режиму, особливо це стосується більш низьких зимових температур. Перераховані вище умови можуть призвести до зниження успішності засвоєння освітніх програм впродовж усього періоду навчання.

На цей час залишається актуальною проблема збереження контингенту іноземних студентів, який значно скорочується після неуспішної здачі заліків та іспитів під час сесій. На думку багатьох авторів, одним $з$ показників, що визначає здатність подолання труднощів процесу пристосування іноземних студентів до українського середовища та виконання вимог навчального процесу $є$ фізичний стан, який містить сукупність взаємопов'язаних ознак: фізичну працездатність, відповідність показників життєдіяльності та ступеня стійкості організму до несприятливих зовнішніх дій, функціональний стан органів і систем та фізіологічних функцій, фізичний розвиток, фізичну підготовленість.

Аналіз останніх досліджень та публікацій показав недостатнє вивчення уявлень про фізіологічні механізми, які підтримують стан здоров'я іноземних студен- тів в системі організм-середовище, необхідність виявлення певних закономірностей у функціонуванні систем організму, у зв'язку з тим, що фізичний стан має неоднорідні тенденції з певними загостреннями і спадами у процесі навчання, що обумовлює актуальність дослідження цих параметрів в умовах навчання у закладах вищої освіти України.

Мета - дати порівняльну характеристику фізичного стану студентів 3 країн Близького Сходу.

Для досягнення мети ставились наступні завдання:

1. На підставі аналізу літературних джерел вивчити інформацію щодо уявлень про основні механізми, які підтримують стан здоров'я іноземних студентів в умовах навчання у закладах вищої освіти України.

2. Вивчити фізичний розвиток студентів 3 Сгипту та Ізраїлю.

3. Визначити параметри рутинних показників діяльності і вегетативної нервової регуляції серцевосудинної системи та фізичної працездатності студентів з Єгипту та Ізраїлю.

4. Проаналізувати рівень фізичного стану студентів з Сгипту та Ізраїлю.

\section{Методи дослідження}

Дослідження проводилося на базі Державного закладу «Південноукраїнський національний педагогічний університет імені К. Д. Ушинського» у лабораторії вікової фізіології спорту імені професора Т. М. Цонєвої кафедри біології і охорони здоров'я. Обстеження фізичного стану студентів-чоловіків IV року навчання з Сгипту $(\mathrm{n}=11)$ середній вік, яких був $23,27 \pm 0,36$ років та Ізраїлю $(\mathrm{n}=12)-23,08 \pm 0,29$ років проведено за наступними взаємодоповнювальними методами: аналіз спеціальної науковометодичної літератури, аналіз параметрів фізичного розвитку та показників діяльності серцево-судинної системи, фізичної працездатності.

Оцінка фізичного розвитку проводилася за допомогою основних антропометричних вимірів: довжини (ДТ, см) та маси тіла (МТ, кг), обводів шиї (см), черева (см), грудної клітки (см), стегна (см), гомілки (см), плеча (см), передпліччя (см), динамометрії кистьової і станової (кг), життєвої ємності легень (мл) та 
3 використанням методів індексів (силовий (\%) та життєвий (мл/кг)).

Показники діяльності серцево-судинної системи: частота серцевих скорочень (ЧСС, хв ${ }^{-1}$ ), артеріальний систолічний (АТс, мм рт. ст.) і діастолічний (АТд, мм рт. ст.) тиск вивчалися як у стані відносного м'язового i психічного спокою, так і за допомогою проби з фізичним навантаженням (Мартіне-Кушелевського). Оцінка стану вегетативної нервової регуляції серцево-судинної системи визначалася за пробами зі зміною положення тіла у просторі (отрто-, кліностатична) та розрахунку вегетативного індексу Кердо. Фізична працездатність іноземних студентів вивчалася за тестом $\mathrm{PWC}_{170}$ (степергометрія).

Математична обробка даних була здійснена за стандартними програмами (Microsoft Excel, Statistica6.0). Вірогідність відмінностей між групами визначалась на підставі непараметричного критерію МаннаУїтні. Достовірними вважалися відмінності між середніми арифметичними значеннями, які не перевищували критичного рівня значущості $(\mathrm{p} \leq 0,05)$.

Дослідження проведені з дотриманням біоетичних норм і міжнародних рекомендацій 3 медикобіологічних досліджень.

\section{Результати}

Характеристика основних параметрів фізичного розвитку, який є сукупністю морфологічних і функціональних властивостей людини, свідчить про переважання деяких показників обстежених ізраїльтян. Так, кистьова динамометрія студентів 3 Ізраїлю (CI) на 18,2\% більша, ніж у студентів з Сгипту (СС). Екскурсія грудної клітки обстежених з Ізраїлю також більше на 12,5\%. Силовий індекс за становою динамометрією студентів з Ізраїлю на 17,6\% більше, ніж у студентів 3 Сгипту, за становою динамометрією також у студентів з Ізраїлю на 57,79\% більше як і за життєвим індексом більше на 21,9\%, але за життєвою ємністю легень (СС - 4440,00 \pm 298,22 мл, СІ $-4600,00 \pm 228,30$ мл), становою динамометрією (СС - 104,44 \pm 7,43 кг, СІ $112,25 \pm 11,18$ кг) та середніми значеннями індексу

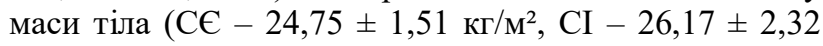
$\kappa г / \mathrm{M}^{2}$ ) відзначалися вірогідно менші відмінності. Являє інтерес той факт, що вірогідно більша $(36,4 \%)$ кількість студентів з Сгипту мала надлишкову МТ, ніж студентів 3 Ізраїлю (8,3\%). Ожиріння I ступеня було виявлено у 16,7\% ізраїльтян (табл. 1).

\section{Показники фізичного розвитку іноземних студентів}

Таблиця 1

\begin{tabular}{|c|c|c|c|c|}
\hline \multirow{3}{*}{$\begin{array}{l}\text { Показники фізичного } \\
\text { розвитку }\end{array}$} & \multicolumn{4}{|c|}{ Значення показників фізичного розвитку } \\
\hline & \multicolumn{2}{|c|}{ студенти з Сгипту } & \multicolumn{2}{|c|}{ студенти з Ізраїлю } \\
\hline & $\bar{x}$ & $m_{x}$ & $\bar{x}$ & $\mathrm{~m}_{\mathrm{x}}$ \\
\hline Довжина тіла стоячи, см & 176,22 & 3,01 & 177,00 & 2,00 \\
\hline Довжина тіла сидячи, см & 90,20 & 2,01 & 91,30 & 1,14 \\
\hline Маса тіла, кг & 75,90 & 4,52 & 79,83 & 3,57 \\
\hline Індекс маси тіла, кг/м² & 24,75 & 1,51 & 26,17 & 2,32 \\
\hline Обвід шиї, см & 38,10 & 1,35 & 37,91 & 0,97 \\
\hline Обвід черева, см & 87,70 & 3,63 & 81,33 & 4,16 \\
\hline Обвід грудної клітки (пауза), см & 88,93 & 5,14 & 95,30 & 2,24 \\
\hline Обвід грудної клітки (вдих), см & 94,80 & 6,03 & 96,25 & 4,20 \\
\hline Обвід грудної клітки (видих), см & 89,00 & 5,79 & 85,30 & 6,12 \\
\hline Екскурсія грудної клітини, см & 6,30 & 0,91 & 7,20 & 0,79 \\
\hline Обвід стегна, см & 62,90 & 3,61 & 63,50 & 1,89 \\
\hline Обвід гомілки, см & 39,44 & 1,67 & 35,42 & 1,23 \\
\hline Обвід плеча у напруженому стані, см & 33,50 & 0,92 & 34,20 & 0,86 \\
\hline Обвід плеча у розслабленому стані, см & 31,20 & 1,24 & 29,58 & 1,02 \\
\hline Обвід передпліччя, см & 27,12 & 0,58 & 28,20 & 1,29 \\
\hline Кистьова динамометрія, кг & 35,30 & 2,22 & 43,17 & 3,66 \\
\hline Силовий індекс (кистьова динамометрія), \% & 44,30 & 3,75 & 61,90 & 3,97 \\
\hline Станова динамометрія, кг & 104,44 & 7,43 & 147,77 & 11,18 \\
\hline Силовий індекс (станова динамометрія),\% & 89,98 & 15,20 & 213,18 & 23,70 \\
\hline Життєва ємність легень, мл & 4440,00 & 298,22 & 4600,00 & 228,30 \\
\hline Життєвий індекс, мл/кг & 166,48 & 9,92 & 213,18 & 23,70 \\
\hline
\end{tabular}

Аналіз даних показав відсутність вірогідних відмінностей між студентами з Сгипту та Ізраїлю за наступними показниками: довжини тіла стоячи $\left(\mathrm{CE}-176,22 \pm 3,01 \mathrm{~cm}\left( \pm \mathrm{m}_{\mathrm{x}}\right), \mathrm{CI}-177,00 \pm 2,00\right)$; сидячи (СС - 90,20 $\pm 2,01 \mathrm{~cm}, \mathrm{CI}-91,30 \pm 1,14 \mathrm{~cm})$; маси тіла (CС - 75,90 $\pm 4,52 \mathrm{~cm}, \mathrm{CI}-79,83 \pm 3,57 \mathrm{~cm})$; обводів шиї $(\mathrm{CE}-38,10 \pm 1,35 \mathrm{~cm}, \mathrm{CI}-37,91 \pm 0,97 \mathrm{~cm})$, черева (CС - 87,70 $\pm 3,63 \mathrm{~cm}, \mathrm{CI}-81,33 \pm 4,16 \mathrm{~cm})$, грудної клітки у паузі (CС - 88,93 $\pm 5,14 \mathrm{~cm}, \mathrm{CI}-95,30 \pm 2,24 \mathrm{~cm})$, на вдиху (СС - 94,8 $\pm 6,03 \mathrm{~cm}, \mathrm{CI}-96,25 \pm 4,20$ см) і видиху (СС $-89,00 \pm 5,79 \mathrm{~cm}, \mathrm{CI}-85,30 \pm 6,12 \mathrm{~cm})$, стегна (СС - 62,90 $\pm 3,61 \mathrm{~cm}, \mathrm{CI}-63,50 \pm 1,89$ см), плеча у напруженому (CE - 33,50 $\pm 0,92 \mathrm{~cm}, \mathrm{CI}-34,20 \pm$ $0,86 \mathrm{~cm})$ і розслабленому стані $(\mathrm{CE}-31,20 \pm 1,24 \mathrm{~cm}$, 
$\mathrm{CI}-29,58 \pm 1,02 \mathrm{~cm})$, передпліччя (CС $-27,12 \pm 0,58$ см, CI - 28,20 $\pm 1,29$ см).

Важливою характеристикою фізичного стану людини є параметри функціонального стану організму, які поєднують психофізіологічну складову особистості, своєрідність функціонування окремих біологічних систем. Як правило, будь-яку характеристику функціонального стану формулюють за допомогою вивчення функціонування кардіореспіраторної системи. Результати оцінки іiі діяльності між групами СС та СI, отримані за найбільш доступними для вимірювання показниками, а саме ЧСС та АТ у стані відносного спокою. Встановлено, що за отриманими даними обстежені обох груп вірогідно ( $\mathrm{p} \leq 0,05)$ не відрізнялися. ЧСС СС - 75,30 \pm 2,12 уд./хв., CI $-77,25 \pm 3,06$ уд./хв.; систолічний артеріальний тиск СЕ - 113,00 $\pm 1,53$ мм рт. ст., CI - 115,67 $\pm 1,52$ мм рт. ст.; діастолічний артеріальний тиск СЄ -

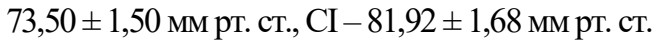

Інтерпретація результатів орто- і кліностатичної проб здійснювалася на підставі врахування безпосередньої реакції організму людини на зміну положення тіла у просторі. Вивчалася сенситивність (чутливість, реактивність) симпатичного чи парасимпатичного відділів вегетативної нервової системи у відповідності підвищення тонусу того чи іншого відділу вегетативної нервової регуляції (рис. 1, 2).

60

Ортостатична проба

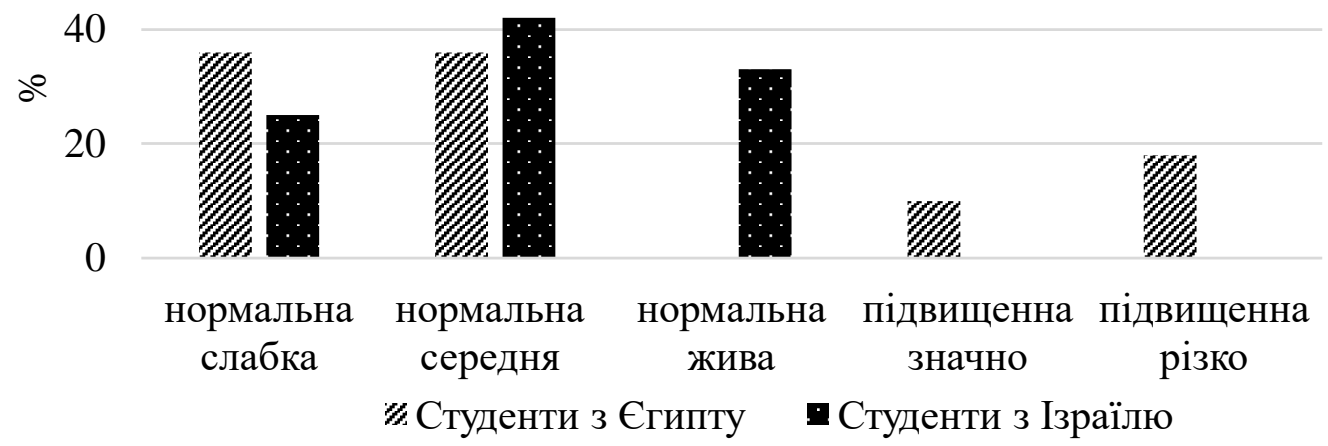

Рис. 1. Реакція прискорення частоти сериевих скорочень іноземних студентів за ортостатичною пробою

У результаті виконання ортостатичної проби реакція прискорення частоти серцевих скорочень «нормальна слабка» спостерігалася у $36 \%$ СЕ і у $25 \%$ CI, у $36 \%$ CЄ та у $42 \%$ СІ була «нормальна середня» реакція. «Нормальну живу» реакцію прискорення частоти серцевих скорочень мали 33\% СІ, у 18\% СЕ спостерігалася реакція «підвищена різко» і у 10\% - «підвищена значно».
За показниками кліностатичної проби 73\% СЄ та 17\% СI мали «нормальну середню» реакцію уповільнення частоти серцевих скорочень, 9\% СЕ та 67\% СI мали «нормальну живу» реакцію, 18\% СЕ і 8\% СI мали «нормальну слабку» реакцію і 8\% СІ мали «підвищену середню» реакції (рис. 2).

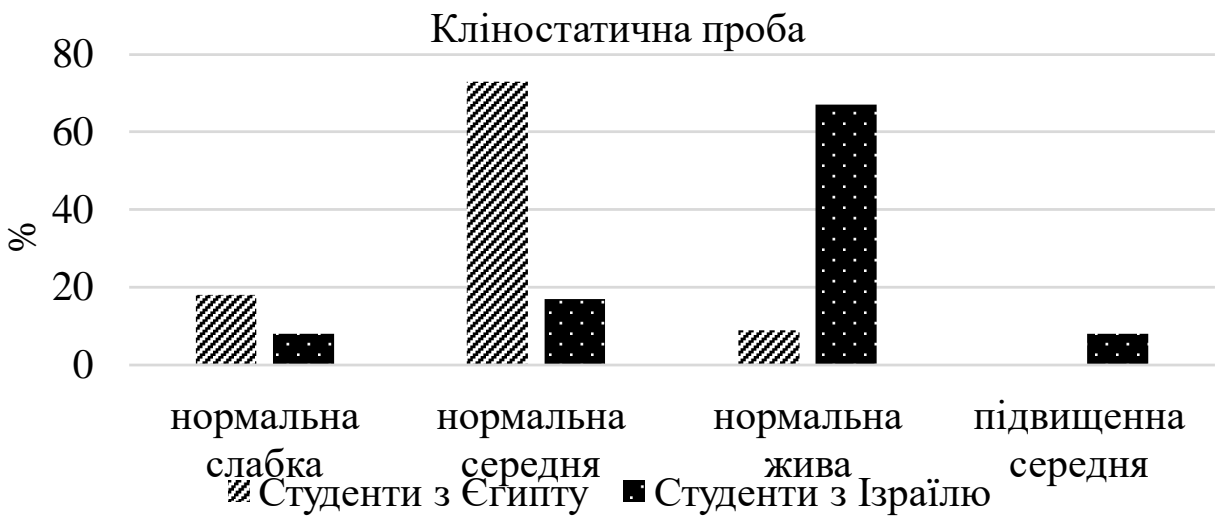

Рис. 2. Реакція уповільнення частоти серцевих скорочень іноземних студентів за кліностатичною пробою

Вивчення механізмів вегетативного забезпечення діяльності серцево-судинної системи, за даними розрахунку вегетативного індексу Кердо (ВІК), показало помірний дисбаланс активності симпатичного відділу вегетативної нервової системи у 27,3\% студентів 3
Єгипту, а у студентів з Ізраїлю, навпаки, помірний (у $16,7 \%$ ) та виражений (у $33,3 \%$ ) дисбаланс активності парасимпатичного відділу вегетативної нервової системи. 
Оцінка результатів проби МартінеКушелевського здійснювалася шляхом визначення типу реакції серцево-судинної системи обстежуваних на фізичне навантаження, виникнення якої пов'язано зі змінами гемодинаміки індивіда, які відбуваються в організмі при виконанні м'язової роботи. Отримані дані свідчать, що обстежені іноземні студенти мали наступні типи реакції серцево-судинної системи на фізичне навантаження: $82 \%$ CС та 92\% CI - нормотензивний тип, 9\% СС мали гіпотензивний та 9\% гіпертензивний типи, 8\% СI мали східчастий тип реакції.
Дослідження фізичної працездатності здійснювалося за допомогою степергометричного варіанту тесту $\mathrm{PWC}_{170}$, який віддзеркалює функціональний стан багатьох фізіологічних систем організму людини, насамперед функціональні можливості кардіореспіраторної системи та системи енергозабезпечення. Аналіз загальної фізичної працездатності іноземних студентів за показником $\mathrm{PWC}_{170}$ показав, що $90 \% \mathrm{CE}$ i $33 \%$ CI мали високий рівень фізичної працездатності, $50 \%$ CI - вище за середній рівень та 10\% СС і 17\% СI мали середній рівень фізичної працездатності (рис. 3).

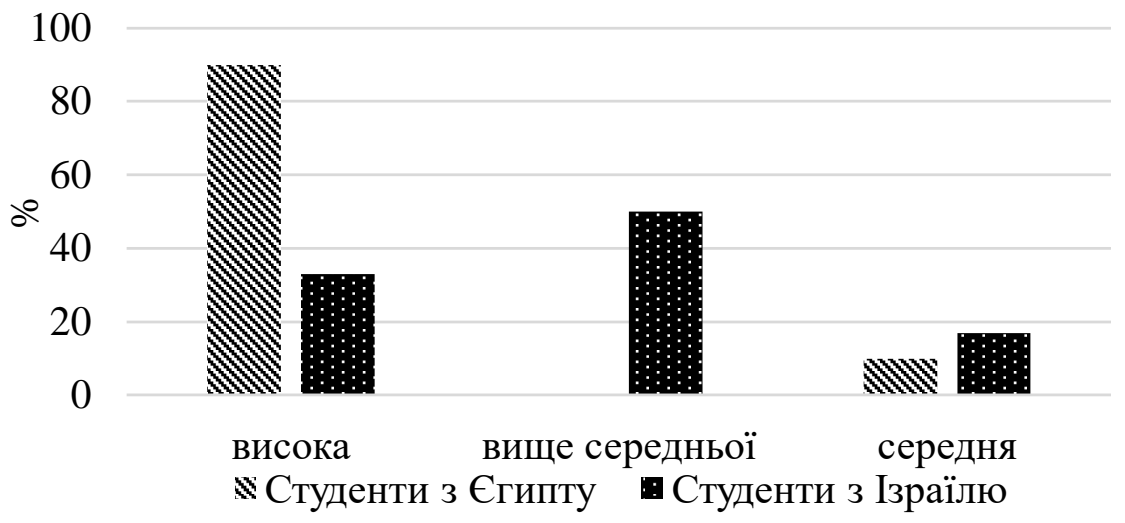

Рис. 3. Очінка загальної фізичної працездатності іноземних студентів за показником РWС ${ }_{170}$

\section{Обговорення}

Порівняльна характеристика фізичного стану студентів з країн Близького Сходу вміщувала вивчення фізичного розвитку, формування якого залежить від унікального генотипу особи і середовищних умов індивідуального розвитку, саме генотип-середовищні взаємодії обумовлюють фенотипічні особливості фізичного розвитку в онтогенезі. Отримані дані демонструють переважання морфофункціональних показників обстежених ізраїльтян, які забезпечують не тільки життєздатність організму, а й оптимальне виконання людиною всіх видів діяльності.

Вагомими, з позицій інтерпретації фізичного стану іноземних студентів, були дані розрахунків параметрів функціонального стану основних біологічних систем, які функціонують в організмі людини завдяки адаптивним механізмам саморегуляції та спрямовані на забезпечення своєчасного гомеокинезіса при реалізації механізмів міжсистемної нейро-імуно-ендокринної регуляції, що визначає пристосувальні та резервні можливості організму, його здатності до вмикання та адекватного перебігу адаптаційних та саногенетичних механізмів.

За індексом Кердо, орто- та кліностатичною пробою, отримані вірогідні $(\mathrm{p} \leq 0,05)$ відмінності між групами обстежуваних, що дозволяє стверджувати про незбалансовану вегетативну регуляцію організму іноземних студентів. Встановлено, що в певній мірі, у СІ схильність до переважання парасимпатикотонічних впливів, тоді як в СС - схильність до переважання симпатикотонічних ефектів.

Визначення типу реакції серцево-судинної системи на фізичне навантаження за допомогою виконання проби Мартіне-Кушелевського показало, що більшість обстежених студентів обох груп мали нормотензивний тип реакції, який вважається сприятливим. Наявність нормотензивного Science and Education, 2020, Issue 1 типу реакції вказує на достатньо оптимальний рівень впливу регуляторних механізмів організму людини на всі ланки системи кровообігу, які забезпечують раціональне пристосування особи до фізичного навантаження. Функціональний стан серцево-судинної системи при цьому оцінюється як добрий або високий. Також, у групах обстежених спостерігалися гіпертензивний $(9 \%)$, гіпотензивний $(9 \%)$ та східчастий (8\%) типи, які є атиповими і вважаються несприятливими. Функціональний стан серцево-судинної системи при атипових типах реакції на фізичне навантаження оцінюється як незадовільний або низький.

Оцінка фізичної працездатності за степергометричним варіантом тесту $\mathrm{PWC}_{170}$ визначала аеробну продуктивність досліджуваних, оскільки фізична працездатність особи значною мірою залежить від включення аеробних процесів та найбільш оптимальним постачальником енергії $\epsilon$ аеробний метаболізм. Отже, у більшості СЕ загальна фізична працездатність була на високому рівні, а у більшості CI на вище за середнім рівнем.

\section{Висновки}

1. Аналіз літературних джерел свідчить про недостатнє вивчення уявлень про фізіологічні механізми, які підтримують стан здоров'я іноземних студентів в умовах навчання у закладах вищої освіти України та актуальність дослідження параметрів фізичного стану, як одного з показників, що визначає здатність подолання труднощів процесу пристосування іноземних студентів до українського середовища та виконання вимог навчального процесу.

2. Дослідження фізичного розвитку, за даними основних антропометричних вимірювань, показало переважання морфофункціональних показників обстежених ізраїльтян в порівнянні зі студентами з Сгипту за життєвим індексом, силовим індексом кистьової та стано- 
вої динамометрії, екскурсією грудної клітки. Вірогідно більша кількість студентів з Сгипту (36,36\%) мала надлишкову масу тіла, ніж студентів з Ізраїлю (8,33\%). Так, отримані дані надають можливість припустити зменшення ризиків виникнення серцево-судинних захворювань у студентів 3 Ізраїлю, серед основних факторів розвитку яких збільшення маси тіла та не достатній рівень життєвого та силових індексів.

3. Вивчення сенситивності відділів вегетативної нервової системи, типів реакції серцево-судинної системи на дозоване фізичне навантаження та фізичної працездатності свідчить, що у більшості обстежених іноземних студентів спостерігалися підвищення тонусу та незбалансована вегетативна регуляція, нор-

\section{Література}

1. Глазков Е. О. Корекція порушень адаптаційних реакцій при зміні клімато-географічних умов перебування в іноземних студентів. Вісник проблем біологї і медицини. Луганськ, 2016. Вип. 1, Т. 1 (126), С. 396-399.

2. Довгодько Т. І. Особливості пропедевтичної підготовки студентів-іноземців та їх психологопедагогічна адаптація у науковому середовищі вищих навчальних закладів. Реализащия традищионных методов и поиск инноваций в процессе подготовки иностранных студентов в современном высшем учебном заведении: материалы междунар. науч.-методич. конф., Харьков, НТУ "ХП", 2008. С. 346-348.

3. Дегтяренко Т. В., Долгієр Є. В. Медикопедагогічний контроль у фізичному вихованні та спорті : підруч. для студентів закладів вищої освіти. Одеса: Атлант ВОИ СОИУ. 2018. 282 с.

4. Мухаммад Л. Ф. Проблеми студентівіноземців в процесі їх адаптації до навчання в українських вишах. Управління в освіті : зб. матеріалів V міжнар. наук.-практ. конф. (м. Львів, 14-16 квіт. 2011 р.), Львів, 2011. С. 212-214.

5. Degtyarenko T. V., Dolgier E. V., Yagotin R. S., Kodzhebash V. F. Psycho-motility of a person in the context of its psychophysiological support and genetic determination. Journal of Physical Education and Sport (JPES). 2019. № 19 (3), Art. 221, Pp. 1526-1531.

6. Fajda O. I., Hrinchenko B. V., Snihur O. V., Barylyak L. G., Zukow W. What Kerdoe's Vegetative Index really reflects? Journal of Education, Health and Sport. 2015. № 5 (12), Pp. 279-288.

7. Momot O., Diachenko-bohun M., Hrytsai N., Grygus I., Stankiewicz B. Creation of a Healthcare Environment at a Higher Educational Institution. Journal of Physical Education and Sport (JPES). 2020. Vol. 20, Art. 138. Pp. 975-981.

8. Nesterchuk N., Grygus I., Ievtukh M., Kudriavtsev A., Sokołowski D. Impact of the wellness

program on the quality of life of students. Journal of Physical Education and Sport (JPES). 2020. Vol. 20, Art. 132. Pp. 929-938.

9. Trofin P.F., Honceriu C., Cojocaru D. Study regarding the validation of an assessment protocol of $\mathrm{VO}_{2 \max }$ on cycle ergometer. Journal of Physical мотензивний тип реакції на фізичне навантаження, високий та вище за середній рівень фізичної працездатності.

4. Отримані результати показали цілком логічні відмінності у діяльності серцево-судинної та вегетативної нервової систем з урахуванням відмінностей фізичного розвитку між студентами з Сгипту та Ізраїлю. За даними проведеного дослідження, виявлено негативний вплив навколишнього середовища на механізми вегетативного забезпечення діяльності серцево-судинної системи, що потребує певної уваги та своєчасної адекватної корекції з метою профілактики розвитку розладів у нервовій діяльності та адаптаційних можливостях організму обстежених.

Education and Sport (JPES). 2013. № 13(4). Pp. 557562 .

\section{References}

1. Glazkov, E. O. (2016). Korektsiia porushen adaptatsiinykh reaktsii pry zmini klimato-heohrafichnykh umov perebuvannia $\mathrm{v}$ inozemnykh studentiv [Correction of maladjustment reactions in international students caused by change in climatic and geographic conditions]. Visnyk problem biolohii $i$ medytsyny -Bulletin of problems biology and medicine, 1, 396-399 [in Ukrainian].

2. Dovgodko, T. I. (2008). Osoblyvosti propedevtychnoi pidhotovky studentiv-inozemtsiv ta yikh psykholoho-pedahohichna adaptatsiia u naukovomu seredovyshchi vyshchykh navchal'nykh zakladiv [Peculiarities of foreign students' propedeutic preparation and their psychological-pedagogical adaptation in the scientific environment of higher educational institution]. Proceedings of the Scientific and Methodical Conference' 08 : Realyzatsyia tradytsyonnykh metodov y poiske innovatsii $v$ protsesse podhotovki inostrannykh studentov $v$ sovremennom vysshem uchebnom zavedenyy - The implementation of traditional methods and the search for innovation in the process of preparing foreign students in a modern institution of higher education. (pp. 346-348). Kharkov: NTU "KhP" [in Ukrainian].

3. Dehtiarenko, T. V. \& Dolgier, Ye. V. (2018). Medyko-pedahohichnyi kontrol u fizychnomu vykhovanni ta sporti [Medical and pedagogical control in physical education and sports]. Odesa: Atlant VOY SOYU [in Ukrainian].

4. Mukhammad, L. F. (2011). Problemy studentivinozemtsiv $\mathrm{v}$ protsesi yikh adaptatsii do navchannia $\mathrm{v}$ ukrainskykh vyshakh [Problems of foreign students in the process of their adaptation to study in Ukrainian universities]. Proceedings of the 5th International Scientific and Practical Conference' 11: V Mizhnarodna naukovopraktychna konferentsiia «Upravlinnia v osviti» - The Fifth International Scientific and Practical Conference "Management in education”. (pp. 212-214). Lviv: Vydavnytstvo Lvivskoi politekhniky [in Ukrainian].

5. Degtyarenko, T. V., Dolgier, E. V., Yagotin, R. S., Kodzhebash, V. F. (2019). Psycho-motility of a person in the context of its psychophysiological support and genetic determination. Journal of Physical Education and Sport (JPES). 19 (3), 1526-1531 [in English]. 
6. Fajda, O. I., Hrinchenko, B. V., Snihur, O. V., Barylyak, L. G., Zukow, W. (2015). What Kerdoe's Vegetative Index really reflects? Journal of Education, Health and Sport, 5 (12), 279-288 [in English].

7. Momot, O., Diachenko-bohun, M., Hrytsai, N., Grygus, I., Stankiewicz, B. (2020). Creation of a Healthcare Environment at a Higher Educational Institution. Journal of Physical Education and Sport (JPES), 20, 975-981 [in English].
8. Nesterchuk, N., Grygus, I., Ievtukh, M., Kudriavtsev, A., Sokołowski, D. (2020). Impact of the wellness program on the quality of life of students. Journal of Physical Education and Sport (JPES), 20, 929938 [in English].

9. Trofin, P., Honceriu, C., Cojocaru, D. (2013). Study regarding the validation of an assessment protocol of $\mathrm{VO}_{2 \max }$ on cycle ergometer. Journal of Physical Education and Sport (JPES), 13 (4), 557-562 [in English].

Evdokiya Dolgier, PhD (Candidate of Sciences of Physical education and sport), associate professor, Department of Biology and Health Care, The State institution "South Ukrainian National Pedagogical University named after K. D. Ushynsky", 26, Staroportofrankivska Str., Odesa, Ukraine,

Marina Fidirko, PhD (Candidate of Pedagogical Sciences), associate professor, National University "Odessa Law Academy", 33, Fountain road, Odessa, Ukraine, Moroz Igor, PhD (Candidate of Pedagogical Sciences), associate professor, Head of the Department of Physical Education, National University "Odessa Law Academy", 33, Fountain road, Odessa, Ukraine, Smoliakova Iryna, PhD (Candidate of Pedagogical Sciences), associate professor, Head of the Department of Physical Education, Odessa National Polytechnic University, 1, Shevchenko Avenue, Odesa, Ukraine.

\section{STUDY OF THE PHYSICAL STATE OF THE STUDENTS FROM MIDDLE EAST COUNTRIES}

The article analyzes the problem of the modern ideas about the physiological mechanisms, which support the health of foreign students in the organism-environment system in the conditions of study in institutions of higher education of Ukraine. The aim is to give a comparative characteristics of student's physical state from Middle East countries. The male fourth-year students from Egypt and Israel have participated in the study. The authors carried out the analysis of special scientific and methodical literature, parameters of physical development and indicators of cardiovascular and autonomic nervous systems, physical work capacity of the foreign students. The study has showed the predominance of morphofunctional indicators of Israelis in comparison with students from Egypt in indicators of life index, strength index of wrist and posture dynamometry, chest excursion. It is probable that most of students from Egypt (36,4\%) had overweight than students from Israel (8,3\%). According to the Kerdoe's Vegetative Index, ortho- and clinostatic tests, which characterize the influence of sympathetic or parasympathetic divisions of autonomic regulation, the probable $(p \leq 0,05)$ differences between the groups of subjects have been obtained, that allows to state that foreign students have the imbalance in the autonomic regulation of body, so, to some extent, students in Israel have a tendency towards predominance of parasympathicotonic influences, while students from Egypt have a tendency towards predominance of sympathicotonic effects. The study of cardiovascular system types of physical activity and physical work capacity shows that most of the foreign students had a normotensive type of reaction to physical exertion, high and above average level of physical work capacity. According to the conducted study, a negative impact of the environment on the mechanisms of autonomic support of the cardiovascular system was revealed, that requires some attention and timely adequate correction in order to prevent disorders of the nervous activity and the adaptive capacities of the students' body in the analyzed groups.

Keywords: foreign students, physical state, physical growth, functional state.

Подано до редакизї 18.05.2020 